\title{
Dorota Jelonek
}

Politechnika Częstochowska

\section{OCENA INTERNETOWYCH KANALÓW KOMUNIKACJI Z KLIENTEM W PROCESIE WSPÓLTWORZENIA INNOWACJI}

\begin{abstract}
Streszczenie: Wraz z rozwojem możliwości informacyjnych i komunikacyjnych Internetu wrasta rola klienta jako partnera w procesie współtworzenia innowacji z zastosowaniem szeroko rozumianego modelu innowacji otwartych. Celem artykułu jest próba oceny kanałów komunikacji stosowanych przez firmy w kontaktach $\mathrm{z}$ klientem. W ocenie wykorzystano wyniki badań ankietowych przeprowadzonych wśród studentów, którzy deklarowali aktywność w zakresie: zgłaszania pomysłów innowacyjnych, testowania produktów (usług) lub podjęcia roli konsultanta. Ocena uwzględniła kryteria wygody, szybkości i skuteczności z perspektywy klienta i reakcji firmy w danym kanale komunikacji. E-mail, sms, forum, blog, portal społecznościowy są wygodne, ale ich stosowanie wykorzystanie przez firmy wymaga poprawy pod względem szybkości reakcji (odpowiedzi) oraz skuteczności. Wysoko pod względem skuteczności i wygody oceniono kanały komunikacji w trybie synchronicznym: telefon, czat, rozmowę wideo i Skype. Najlepszym, ale wciąż mało rozpowszechnionym rozwiązaniem są platformy do zgłaszania pomysłów i współpracy z użytkownikiem tworzone na portalach firmowych.
\end{abstract}

Słowa kluczowe: internetowe kanały komunikacji, efektywność internetowych kanałów komunikacji, współtworzenie, innowacje.

DOI: $10.15611 /$ ie.2014.1.24

\section{Wstęp}

Kompetencje przedsiębiorstwa w obszarze tworzenia i wdrażania innowacji mogą istotnie stanowić o jego pozycji konkurencyjnej na rynku. Konkurencyjność w aspekcie innowacji sprowadza się do wprowadzenia proinnowacyjnej strategii działania, otwartości na nowe pomysły pracowników i klientów, kształtowania proinnowacyjnych postaw kierownictwa i pracowników. Każda organizacja musi nauczyć się innowacji jako systematycznego procesu, jako że innowacja może i musi być teraz zorganizowana [Drucker 2010]. Innowacje mogą dotyczyć produktów (usług), wykorzystywanej technologii, przebiegu procesów, podejmowanych dzia- 
łań marketingowych czy zmian organizacyjnych i zarządczych. Każda zmiana innowacyjna może być inicjowana przez źródła wewnętrzne przedsiębiorstwa (endogeniczne) lub źródła zewnętrzne innowacji (egzogeniczne). Ze względu na przyczynę powstawania innowacji można je podzielić na [Janasz, Kozioł 2007]:

- popytowe - inicjowane przez rynek,

- podażowe - inicjowane przez naukę i technikę.

Przedmiotem dalszych rozważań będą innowacje współtworzone z konsumentami (klientami). Ten model tworzenia innowacji jest przykładem wykorzystania źródeł egzogenicznych innowacji, odpowiada popytowym tendencjom kreowania innowacji i ukierunkowuje proinnowacyjną działalność przedsiębiorstwa na adaptację modelu innowacji otwartych. Celem artykułu jest próba oceny kanałów komunikacji z których korzystają firmy w kontaktach z klientem w procesie współtworzenia innowacji. Zostaną zaprezentowane kierunki aktywności innowacyjnej przedsiębiorstwa, ze szczególnym uwzględnieniem modeli innowacji angażujących klientów. Kolejne rozważania będą dotyczyć dwóch istotnych czynników sukcesu współpracy z klientem: motywowania i zaangażowania klienta do współpracy oraz doboru najbardziej efektywnych internetowych kanałów komunikacji z klientem.

W części empirycznej przedstawiono wyniki badań ankietowych przeprowadzonych wśród studentów, którzy deklarowali aktywność w zakresie współpracy z przedsiębiorstwami w obszarze zmian innowacyjnych. Ocena wykorzystywanych kanałów komunikacji nie obejmuje aspektów technologicznych omawianych rozwiązań, a kryteria wygody, szybkości i skuteczności ich zastosowania dotyczą doświadczeń z perspektywy klienta i reakcji firmy na komunikaty przesyłane za pomocą danego rozwiązania.

\section{Kierunki aktywności innowacyjnej przedsiębiorstw}

Aktywność innowacyjna oraz zdolność do szybkiego i efektywnego wdrażania innowacji to istotne atrybuty przedsiębiorstwa, które ukierunkowane jest na rozwój i stałe umacnianie swojej pozycji na rynku. Magazyn „Business Week” i Boston Consulting Group ${ }^{1}$ przeprowadziły badanie wśród ponad 1500 menedżerów w celu identyfikacji innowacyjnych marek i trendów w kreowaniu innowacji. Dla 83\% uczestników badania to właśnie innowacyjność będzie uważana za element, który może stać się przyczyną przewagi konkurencyjnej na dźwigającym się po kryzysie rynku. Kolejne $72 \%$ menedżerów uważa badania i rozwój za swój priorytetowy cel do realizacji na przestrzeni najbliższych miesięcy tego roku, a $61 \%$ planuje nawet istotne inwestycje na realizację tego celu.

\footnotetext{
${ }^{1}$ Business Week/WARC, cyt. za: MEDIA NA ŚWIECIE: Ranking innowacyjności marek, http://marketing.org.pl/.
} 
W świetle powyższych wniosków przedsiębiorstwa powinny stawać się coraz bardziej innowacyjne, czyli elastyczne i otwarte na pozyskiwanie nowych pomysłów i zmierzające do wypracowania efektywnych procedur weryfikacji, doskonalenia i wdrażania innowacyjnych pomysłów. Innowacyjność organizacji może być definiowana jako chęć (skłonność) do bycia innowacyjnym oraz zdolność do wprowadzania nowych produktów, usług czy idei, aż po ich wdrażanie, które prowadzi do poprawy wyników biznesowych [Dobni 2010]. Najważniejsze cechy organizacji innowacyjnej to [Peters, Waterman 2000]:

- bliskie i systematyczne kontakty z klientami i partnerami biznesowymi,

- traktowanie pracowników jako podstawowego źródła jakości i wzrostu wydajności,

- autonomia i przedsiębiorczość,

- aktywne zaangażowanie i kierowanie się wartościami,

- prostota organizacyjna (minimalna administracja),

- działanie we własnej domenie,

- umiejętność łączenia „luzu i sztywności”.

Powyższą listę cech organizacji innowacyjnej można jeszcze uzupełnić o następujące:

- organizacja ma wypracowane procedury kontaktu z klientem - potencjalnym pomysłodawcą,

- w strukturze organizacji są jednostki i osoby odpowiedzialne za utrzymywanie i rozwijanie relacji z klientami,

- informatyczna infrastruktura organizacji jest dostosowana do adaptacji nowych internetowych kanałów komunikacji z klientem,

- kierownictwo organizacji akceptuje podejmowanie ryzyka,

- klienci-innowatorzy są nagradzani.

Przedsiębiorstwo innowacyjne powinny także cechować intensywne interakcje z otoczeniem, zwłaszcza z potencjalnymi innowatorami. Fakt, że klienci i użytkownicy produktu lub usługi coraz częściej są lub chcą być współautorami innowacji, znalazł odzwierciedlenie $\mathrm{w}$ kilku koncepcjach tworzenia innowacji:

- koncepcji innowacji otwartych [Chesbrough 2003],

- koncepcji tworzenia wartości przy współudziale konsumentów value cocreation [Prahalad, Ramaswamy 2003],

- koncepcji przewodnictwa klienta user-driven innovation (UDI), która w pełni przekazuje inicjatywę tworzenia innowacji i nadzór nad tym procesem konsumentom [Rosted 2005],

- koncepcji experience innovation, której źródłem są doświadczenia (eksperymenty) klientów [Prahalad, Ramaswamy 2003a],

- crowdsourcing [Busarovs 2011, Howe 2008],

- hacking produktów, czyli modyfikowanie zakupionych produktów, ich ulepszanie i dostosowywanie do swoich potrzeb. 
Lista nie jest pełna i z pewnością będą się na niej pojawiać nowe propozycje modeli innowacji ukierunkowane na zaangażowanie do współpracy klientów. Dla innowacyjnych przedsiębiorstw powyższe koncepcje mogą być wskazówką, jak ukierunkować swoją aktywność innowacyjną, aby osiągać zamierzone celu rozwoju i umacniania pozycji wśród konkurentów.

\section{Zwiększanie zaangażowana klienta do wspólpracy}

Dla przedsiębiorstw, które chcą współpracować z konsumentem w procesie tworzenia innowacji, istotna powinna być znajomość motywów, jakimi konsumenci się kierują, podejmując określone współdziałanie. $\mathrm{W}$ badaniach ${ }^{2}$ wykazano, że bardzo ważne dla klientów motywy podjęcia współpracy z firmą to [Jelonek 2013]:

- personalizacja oferty $(96 \%)$,

- zmniejszenie niezadowolenia z produktu (88\%),

- korzystanie z opinii i wskazówek innych konsumentów (76\%),

- chęć otrzymania produktu lub usługi, które są lepiej dopasowane do indywidualnych potrzeb i preferencji (52\%).

Tabela 1. Zwiększanie zaangażowania klienta we współpracę

\begin{tabular}{|c|c|c|}
\hline Działania & Opis działania & $\begin{array}{c}\text { Rozszerzenie działań } \\
\text { dla współtworzenia innowacji }\end{array}$ \\
\hline Słuchanie & $\begin{array}{l}\text { Regularny monitoring rozmów, } \\
\text { które klienci prowadza, jako alter- } \\
\text { natywa dla badań ankietowych } \\
\text { i wywiadów zogniskowanych }\end{array}$ & $\begin{array}{l}\text { Regularny monitoring korespondencji e-mail, fo- } \\
\text { rum, blogów, formularzy na stronie firmowej, } \\
\text { aktywności w portalach społecznościowych itp. }\end{array}$ \\
\hline Komunikowanie się & $\begin{array}{l}\text { Uczestniczenie w rozmowach } \\
\text { i stymulowanie dwukierunkowej } \\
\text { wymiany poglądów między klien- } \\
\text { tami jako alternatywa dla jedno- } \\
\text { stronnych komunikatów }\end{array}$ & $\begin{array}{l}\text { Uczestnictwo we wszystkich formach komunika- } \\
\text { cji z klientem }\end{array}$ \\
\hline Inspirowanie & $\begin{array}{l}\text { Umożliwienie najbardziej entuzja- } \\
\text { stycznie nastawionym klientom } \\
\text { sprzedawanie produktów }\end{array}$ & $\begin{array}{l}\text { Umożliwienie klientom zgłaszania swoich pomy- } \\
\text { słów innowacyjnych z wykorzystaniem prefero- } \\
\text { wanych przez nich kanałów komunikacji }\end{array}$ \\
\hline Wspieranie & $\begin{array}{l}\text { Stwarzanie klientom możliwości } \\
\text { udzielenia wzajemnego wsparcia }\end{array}$ & $\begin{array}{l}\text { Udzielanie odpowiedzi na komunikaty klientów } \\
\text { i informacji, czy pomysł będzie rozważany, w ja- } \\
\text { kim terminie i czy klient będzie informowany } \\
\text { o postępie prac }\end{array}$ \\
\hline Zaangażowanie & $\begin{array}{l}\text { Zachęcanie klientów do wspólnej } \\
\text { pracy nad rozwiązaniami, które } \\
\text { pozwolą podnieść jakość produk- } \\
\text { tów lub usług }\end{array}$ & $\begin{array}{l}\text { Zaangażowanie w interaktywny dialog z klientem. } \\
\text { Ogłaszanie konkursów na nowe rozwiązania. Na- } \\
\text { gradzanie aktywnych klientów }\end{array}$ \\
\hline
\end{tabular}

Źródło: opracowanie własne z wykorzystaniem [Li, Bernoff 2000].

\footnotetext{
${ }^{2}$ Badania przeprowadzono w 2013 r. w grupie 240 respondentów, w wieku od 18 do 35 lat.
} 
O wiele mniej ważne były motywy dotyczące [Jelonek 2013]:

- możliwości współtworzenia oferty (33\%),

- możliwości prezentacji innowacyjnych pomysłów na doskonalenie oferowanych produktów $(29 \%)$,

- możliwości rozwiązywania problemów (doradztwo eksperta) (25\%),

- możliwości dzielenia się wiedzą (18\%),

- możliwości tworzenia relacji (16\%),

- możliwości budowania własnego wizerunku w Internecie (14\%).

Powyższe wyniki jednoznacznie wskazują, że przedsiębiorstwa muszą wypracować własne formy zaangażowania, a następnie efektywnej współpracy z klientami z uwzględnieniem personalizacji jako determinanty sukcesu podjętych działań [Jelonek 2014]. Li i Bernoff [2000] proponują na sposoby zwiększenia zaangażowania klientów spojrzeć z perspektywy mechanizmów społecznościowych w ramach modelu pięciu działań przedstawionych w tabeli 1.

Drugi istotny czynnik sukcesu efektywnej współpracy z klientem to wygodna i skuteczna komunikacja z klientem.

\section{Wybrane kanały komunikacji z klientem w Internecie}

Determinantą popularności modeli innowacji otwartych jest niewątpliwie dynamiczny rozwój nowych internetowych kanałów komunikacji. Przedsiębiorstwa powinny budować ofertę wielokanałowości w kontaktach z klientem. Użytkownicy Internetu nie stanowią jednolitej grupy pod względem preferencji korzystania z rozwiązań komunikacyjnych i każdy $z$ nich indywidualnie decyduje, czy proponowana oferta komunikowania się z firmą jest dla niego wygodna i czy z niej skorzysta.

Powszechnie znane i wykorzystywane internetowe środki komunikacji klienta $\mathrm{z}$ firmą to: email, formularze na stronie internetowej, blog na portalu firmowym, czat na stronie firmowej, rozmowa wideo i Skype. Od kilku lat coraz większe znaczenie zyskują portale społecznościowe [Reinhold, Alt 2012] oraz platformy współpracy z klientem w obszarze innowacji. Przedsiębiorstwa wykorzystują media społecznościowe jako efektywne narzędzie do pozyskiwania nowych i utrzymania dotychczasowych klientów oraz zachęcanie ich do dzielenia się sugestiami i pomysłami oraz angażowania klientów do prac nad tworzeniem i rozwojem produktów i usług.

Reinhold i Alt [2012] podkreślają, że media społecznościowe mogą z powodzeniem być stosowane jako platforma współpracy, która ułatwiania i wspiera współpracę członków wirtualnych społeczności, np. w celu kreowania innowacji, opracowania nowych produktów lub pomysłu na kampanię marketingową. Na pytanie: jak w praktyce media społecznościowe są wykorzystywane przez przedsiębiorstwa, odpowiedź można uzyskać, śledząc wyniki badań zrealizowanych przez firmę Deloitte w roku $2011^{3}$.

${ }^{3}$ Biznes spolecznościowy - nowa era w komunikacji biznesowej, Raport na podstawie badania „Polskie firmy na Facebooku - portale społecznościowe w komunikacji marketingowej polskich przedsiębiorstw", 2011, Deloitte, https://www.deloitte.com, 10.04.2014. 
Na pytanie o cel obecności przedsiębiorstwa w mediach społecznościowych największy odsetek wskazań dotyczył „pozytywnego wpływu na wizerunek marki” (59\%), ,podążania za trendami widocznymi na rynku i u konkurencji” (62\%), natomiast aspekt współpracy z klientem jest uwzględniony w odpowiedziach ,zdobycie wiedzy na temat konsumentów/klientów w tym także potencjalnych" (35\%). Niewielka liczba firm zaznaczyła, że angażuje media społecznościowe w celu zwiększenia sprzedaży czy obniżenia kosztów pozyskiwania klientów. Może to oznaczać, że firmy wciąż nie definiują wyraźnych celów biznesowych obecności w mediach społecznościowych, i nie stosuje np. do współtworzenia innowacji z klientami. Z drugiej strony $\mathrm{w}$ odpowiedziach na pytanie o grupy docelowe, z którymi nawiązywana jest komunikacja w mediach społecznościowych, aż $75 \%$ wskazało „konsumentów/klientów”, a 82\% „potencjalnych konsumentów/klientów”. Badanie pokazało także, że zamieszczane treści są skierowane do tych grup: konkursy $(75 \%)$, multimedia (65\%), aplikacje (37\%), programy lojalnościowe $(10 \%)$.

Podsumowując, firmy traktują media społecznościowe częściej jako narzędzie doraźnej komunikacji aniżeli narzędzie budowy trwałych relacji. Pozytywne jest jednak coraz większe zainteresowanie firm jak posługiwać się tym kanałem komunikacji z klientami.

Najbardziej profesjonalnym rozwiązaniem w komunikacji z pomysłodawcami innowacji są platformy współpracy tworzone na portalach firmowych lub jako niezależne portale. Poniżej zostaną przedstawione trzy przykłady platformy współpracy i wymiany opinii: „Bank pomysłów” BZ WBK, platforma „Dell Idea Storm” oraz platforma „My Starbucks idea”.

Do „Banku pomysłów”4 BZ WBK użytkownicy Facebooka mogą logować się swoim loginem ze społeczności Facebook bez konieczności rejestracji. Klienci generują pomysły dotyczące zmiany oferty banku i stworzyli ich prawie 2000. Na platformie „Dell Idea Storm” zakładki „Ideas”, „Storm sessions” i „Submit your idea” pozwalają każdemu zarejestrowanemu użytkownikowi głosować i komentować pomysły innych osób oraz zgłaszać swoje pomysły. Globalna społeczność klientów Dell powstała w 2007 r. i od tego czasu zgłosiła 13778 pomysłów, a firma Dell wdrożyła 410 z nich. Platfoma „My Starbucks idea"6 oferuje swoim użytkownikom aktywność w zakresie „Got an idea?”, „View ideas” oraz „Ideas in action”. Jasna i przejrzysta struktura sugeruje skupienie się na generowaniu pomysłów, głosowaniu, komentowaniu i wdrażaniu pomysłów. Platformę rozbudowano o ankiety i sondy na zasadzie „Pytanie Dnia” oraz blog relacjonujący postępy w pracach. W ramach nagradzania użytkowników platforma wykorzystuje mechanizm budowania autorytetu i statusu w formie rankingu najaktywniejszych użytkowników.

\footnotetext{
4 https://bankpomyslow.bzwbk.pl/.

5 http://www.ideastorm.com/, 20.04.2014.

$6 \mathrm{http}: / /$ mystarbucksidea.force.com/220.04.2014.
} 
Każda z wymienionych firm przyznaje, że współpraca z użytkownikami (klientami) przynosi firmie wymierne korzyści. Kreatywność klientów, pomoc w testowaniu rozwiązań i udział klientów w roli konsultantów i ekspertów to tylko wybrane aspekty współpracy z klientem.

Na rynku są także dostępne narzędzia wielostronnej komunikacji w czasie rze-

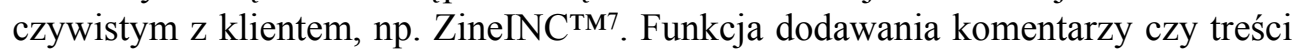
$\mathrm{z}$ poziomu użytkownika $\mathrm{w}$ otwartych kanałach daje możliwość dzielenia się nowymi pomysłami i rozwiązaniami i pozwala na kolektywne poszukiwanie rozwiązań. Jest również miejscem doskonalenia pomysłów w ramach crowdsourcingu. Ponadto ZineINCTM to nie tylko szybka wymiana informacji, ale również współpraca $\mathrm{w}$ czasie rzeczywistym, pozwalająca na bieżące dzielenie się wiedzą, co skutkuje jej przyrostem, który można monitorować za pomocą narzędzia komunikacyjnego [Zineinc 2014].

W komunikacji z klientem-innowatorem wykorzystanie interaktywnych przestrzeni, które umożliwiają dzielenie się zarówno treściami tekstowymi, jak i multimedialnymi, pozwala na budowanie zaangażowania oraz tworzenie społeczności wokół proponowanych inicjatyw.

\section{Zaangażowanie studentów w tworzenie innowacji w ramach modelu otwartego. Wyniki badań własnych}

Badania ankietowe przeprowadzono w styczniu 2014 r. w grupie 198 studentów 8 124 kobiet (63\%) i 73 mężczyzn (37\%) w wieku 23-25 lat. Ustalono, że w badanej grupie $93 \%$ respondentów ma swobodny dostęp do Internetu, 5\% ograniczony dostęp, $1 \%$ bardzo ograniczony, a $1 \%$ brak dostępu. Respondentów cechują ,wysokie” (34\%) i „wystarczające” (57\%) umiejętności w korzystaniu z zasobów Internetu i posługiwaniu się dostępnymi usługami internetowymi. Tylko $6 \%$ badanych przyznało, że „czasem korzysta z pomocy innych”, $2 \%$ „często korzysta z pomocy innych" i $2 \%$,nie potrafi korzystać z Internetu, tak aby zrobić zakupy”.

W identyfikacji zachowań respondentów jako klientów w Internecie wykorzystano ich odpowiedzi na pytanie: „Moją postawę jako klienta w Internecie najlepiej określa". W tabeli 2. przedstawiono wyniki identyfikacji postaw klientów.

Zestawienie odpowiedzi na pytanie: „Czy kiedykolwiek podjąłeś działania w Internecie, w których byłeś: nabywcą produktów lub usług, promotorem marki, klientem, który ujawnia zalety i wady produktu/usługi, innowatorem zgłaszającym pomysł, klientem testującym nowy produkt/usługę lub konsultantem?" przedstawiono w tabeli 3. Odpowiedzi udzieliło 55 respondentów i można było wskazać kilka odpowiedzi.

\footnotetext{
${ }^{7} \mathrm{https}: / /$ zineinc.com/pl/2 20.04.2014.

${ }^{8} \mathrm{~W}$ badaniach uczestniczyli studenci Wydziału Zarządzania Politechniki Częstochowskiej.
} 
Tabela 2. Identyfikacja typu klienta

\begin{tabular}{|l|c|c|l|}
\hline $\begin{array}{l}\text { Propozycje odpowiedzi na pytanie: „Moją postawę } \\
\text { jako klienta w Internecie najlepiej określa”: }\end{array}$ & $\begin{array}{c}\text { Liczba } \\
\text { wskazań }\end{array}$ & \% wskazań & \multicolumn{1}{|c|}{ Typ klienta } \\
\hline Nigdy nie dokonałem zakupów w Internecie & 10 & 5 & Klient tradycyjny \\
\hline $\begin{array}{l}\text { Bardzo rzadko robię zakupy w Internecie, mniej niż } \\
5 \text { razy w ostatnim roku }\end{array}$ & 79 & 40 & $\begin{array}{l}\text { Klient tradycyjny, który } \\
\text { okazjonalnie dokonuje } \\
\text { zakupów w Internecie }\end{array}$ \\
\hline $\begin{array}{l}\text { Lubię zakupy w Internecie i w ostatnim roku więcej } \\
\text { niż 5 razy dokonałem zakupu }\end{array}$ & 53 & 27 & e-Klient* \\
\hline $\begin{array}{l}\text { Często kupuję w Internecie w ostatnim roku więcej } \\
\text { niż 5 razy zrobiłem zakupy. Napisałem co najmniej } \\
\text { jedną opinię o producie /usłudze/ producencie lub/i } \\
\text { przed dokonaniem zakupów zapoznałem się z } \\
\text { opiniami innych klientów o } \\
\text { produkcie/usłudze/producencie }\end{array}$ & 55 & 28 & Prosument** \\
\hline Razem: & 198 & 100 & \\
\hline
\end{tabular}

* W definicji e-klienta wykorzystano zmodyfikowane kryterium przyjęte w ogólnopolskim badaniu przeprowadzonym przez firmę Gemius w 2008 r. W badaniu z 2008 r. przyjęto, że e-klient to użytkownik Internetu, który dokonał zakupu w sklepie internetowym co najmniej raz w ciągu 12 miesięcy poprzedzających badanie.

** W definicji prosumenta wykorzystano zmodyfikowane kryterium przyjęte $\mathrm{w}$ ogólnopolskim badaniu przeprowadzonym przez firmę Gemius w $2008 \mathrm{r}$. W badaniu z $2008 \mathrm{r}$. prosument spełnił co najmniej dwa z trzech warunków: spotyka się z opiniami innych internautów i najczęściej sam ich poszukuje, gdy planuje zakup produktu, sam opisuje produkty i marki w sieci lub zadaje pytania na ich temat, uczestniczy w promocjach, w których współtworzy produkty, hasła lub kampanie reklamowe.

Źródło: opracowanie własne na podstawie wyników badań.

Tabela 3. Aktywności klientów w obszarze działań innowacyjnych

\begin{tabular}{|l|r|}
\hline \multicolumn{1}{|c|}{$\begin{array}{c}\text { Propozycje odpowiedzi na pytanie: „Czy kiedykolwiek podjąłeś działania } \\
\text { w Internecie, w których byłeś”: }\end{array}$} & \% wskazań \\
\hline $\begin{array}{l}\text { Klient zgłaszający pomysł nowego produktu/usługi, lub istotnych usprawnień, } \\
\text { modyfikacji, rozbudowy istniejących produktów lub usług }\end{array}$ & 9 \\
\hline Klient testujący nowy produkt lub usługę & 52 \\
\hline Klient - konsultantem & 40 \\
\hline Razem: & 100 \\
\hline
\end{tabular}

Źródło: opracowanie własne na podstawie wyników badań.

O odpowiedzi na kolejne pytania pytano tylko studentów współpracujących z firmami w obszarze szeroko rozumianych innowacji. Każdy z 55 respondentów mógł wskazać kilka odpowiedzi. Zestawienie odpowiedzi na pytanie „Jakie kanały komunikacji z firmą wykorzystywali respondenci?" przedstawiono w tabeli 4 . 
Tabela 4. Kanały komunikacji z firmą wykorzystywane przez respondentów

\begin{tabular}{|l|c|}
\hline Propozycje odpowiedzi na pytanie: ,Jakie kanały komunikacji z firmą wykorzystywałeś”: & \% wskazań \\
\hline Telefon & 98 \\
\hline Sms & 86 \\
\hline E-mail & 99 \\
\hline Formularz na stronie internetowej & 85 \\
\hline Blog na portalu firmowym & 45 \\
\hline Czat na stronie internetowej & 57 \\
\hline Rozmowę wideo i Skype & 58 \\
\hline Portal społecznościowy & 62 \\
\hline Platforma zgłaszania pomysłów stworzona na stronie WWW przez firmę & 4 \\
\hline Platforma współpracy w trybie rzeczywistym & 0 \\
\hline
\end{tabular}

Źródło: opracowanie własne na podstawie wyników badań.

W ocenie efektywności kanałów komunikacji klientów z firmą uwzględniono trzy kryteria:

- wygody - w skali „mało wygodny”, „średnio wygodny”, „,bardzo wygodny”;

- szybkości - w skali „powolny”, ,średnio szybki”, „bardzo szybki”;

- skuteczności - skali „,mało skuteczny”, „średnio skuteczny”, „,bardzo skuteczny”.

Oceny były subiektywne i nie uwzględniały techniczno-technologicznych możliwości wykorzystywanych kanałów komunikacji, a jedynie aspekt stosowania ich przez firmy. Jak szybko firmy reagują na komunikaty klientów i przesyłają informacje zwrotne oraz na ile, w ocenie użytkowników, posługiwanie się danym kanałem komunikacji jest skuteczne. Ważnym elementem oceny było także kryterium „wygody” w korzystaniu ze środków komunikacji. W tabeli 5. przedstawiono wyniki oceny efektywności kanałów komunikacji dla wskazań „bardzo wygodny”, „bardzo szybki” i „bardzo skuteczny”.

Tabela 5. Ocena wykorzystywanych kanały komunikacji z firmą w kryteriach: wygoda, szybkość, skuteczność

\begin{tabular}{|l|c|c|c|}
\hline \multirow{2}{*}{\multicolumn{2}{c|}{ Kanały komunikacji z firmą }} & \multicolumn{2}{c|}{ Kryteria oceny kanału komunikacji } \\
\cline { 2 - 4 } & wygoda & szybkość & skuteczność \\
\cline { 2 - 4 } & $\begin{array}{c}\text { „bardzo } \\
\text { wygodny” }\end{array}$ & $\begin{array}{c}\text { „bardzo } \\
\text { szybki” }\end{array}$ & $\begin{array}{c}\text { „bardzo } \\
\text { skuteczny” }\end{array}$ \\
\hline Telefon & $90 \%$ & $82 \%$ & $81 \%$ \\
\hline Sms & $75 \%$ & $45 \%$ & $30 \%$ \\
\hline E-mail & $92 \%$ & $80 \%$ & $95 \%$ \\
\hline Formularz na stronie internetowej & $93 \%$ & $79 \%$ & $79 \%$ \\
\hline Blog na portalu firmowym & $52 \%$ & $38 \%$ & $67 \%$ \\
\hline Czat na stronie internetowej & $87 \%$ & $68 \%$ & $85 \%$ \\
\hline Rozmowę wideo i Skype & $89 \%$ & $65 \%$ & $87 \%$ \\
\hline Portal społecznościowy & $48 \%$ & $36 \%$ & $38 \%$ \\
\hline $\begin{array}{l}\text { Platforma zgłaszania pomysłów } \\
\text { stworzona na stronie WWW przez firmę }\end{array}$ & $40 \%$ & $36 \%$ & $42 \%$ \\
\hline Platforma współpracy w trybie rzeczywistym & $45 \%$ & $52 \%$ & $51 \%$ \\
\hline
\end{tabular}

Źródło: opracowanie własne na podstawie wyników badań. 
Dla klientów kontaktujących się z firmą ważne jest, aby oferta dostępnych narzędzi komunikacji była szeroka, w pełni dostępna i skuteczna. Najpopularniejszym kanałem kontaktu jest telefon, a spośród internetowych narzędzi komunikacji e-mail. Są one także wysoko oceniane jako wygodne i skuteczne. Co do szybkości, oceny są niższe i wskazują, że czas uzyskania połączenia lub otrzymania odpowiedzi na e-mail są zbyt długie. Podobną i stosunkowo wysoką ocenę otrzymał formularz na stronie internetowej. Czat na stronie internetowej oraz rozmowy wideo i Skype były nisko ocenione pod względem ,szybkości”, a w ocenie uwzględniono długi czas oczekiwania, często brak aktywności nawet w godzinach wyznaczonych konsultacji. Portale społecznościowe uzyskały niską ocenę skuteczności i szybkości.

Platformy zgłaszania pomysłów stworzone na stronie WWW przez firmy lub platformy współpracy w trybie rzeczywistym największy procent wskazań uzyskały w ocenie „średni”, ponieważ respondenci mieli małe własne doświadczenia z takiej współpracy. Stąd tak niskie oceny efektywności platform w aspektach: „bardzo wygodny”, „bardzo szybki” czy bardzo skuteczny”.

\section{Zakończenie}

Współpraca firmy z klientem (potencjalnym klientem) w obszarze współtworzenia innowacji może przynosić bardzo dobre rezultaty, co potwierdzają spektakularne sukcesy produktów: Linux, Apache, Libre Office, Gimp, Firefox, Google Chrome, Android oraz innowacyjnych firm: Google, Apple, P\&G, HP, Adidas, Lego i wielu innych. We współpracy z klientem ważne są: oferta szerokiej gamy dostępnych kanałów komunikacji, łatwość komunikacji, szybkość reakcji firmy, skuteczność podejmowanych kontaktów oraz ,zapamiętywanie" przez firmę swoich klientów-innowatorów.

Ograniczenie dostępnych metod komunikacji może skutkować zniechęceniem klienta i jego rezygnacją z dalszych prób kontaktu z firmą. Szybka reakcja firmy to okazanie szacunku klientowi, a zwłaszcza czasu, jaki poświęca na kontakty z firmą. Osoby odpowiedzialne za kontakty z klientami powinny mieć zapewniony dostęp do wszystkich informacji o kliencie, do korespondencji z klientem, do firmowych baz danych, tak aby w kontaktach z klientem mogły natychmiast odpowiadać na pytania, podejmować decyzje, podpowiadać rozwiązania, sterować i zarządzać procesem współpracy. Dla organizacji innowacyjnych istotnym wsparciem w procesach współtworzenia innowacji i zarządzania kontaktami z klientem-innowatorem mogą być rozwiązania systemów klasy Zarządzania Relacjami z Klientem (Customer Relationship Management, CRM) oraz ich modyfikacje, np. Social Customer Relationship Management (sCRM). 


\section{Literatura}

Biznes spolecznościowy - nowa era w komunikacji biznesowej, Raport na podstawie badania „Polskie firmy na Facebooku - portale społecznościowe w komunikacji marketingowej polskich przedsiębiorstw", 2011, Deloitte, https://www.deloitte.com (10.04.2014).

Busarovs A., 2011, Crowdsourcing As User-Driven Innovation, New Business Philosophy's Model, "Journal of Business Management", no. 4, s. 53-59.

Business Week/WARC, cyt. za: MEDIA NA ŚWIECIE: Ranking innowacyjności marek, http://marketing.org.pl/.

Chesbrough H., 2003, Open Innovation: The New Imperative for Creating and Profiting from Technology, Harvard Business School Press, Boston.

Dobni C.D., 2010, The Relationship Between and Innovation Orientation and Competitive Strategy, "International Journal of Innovation Management", vol. 14, no. 2 (April).

Drucker P.F., 2010, Classic Drucker, MT Biznes Sp. z o. o., Warszawa.

GemiusReport, 2009, Internauci - konsumenci czy prosumenci? 2008, [w:] Polski Internet 2008/2009, Warszawa.

Howe J., Crowdsourcing: Why the Power of the Crowd Is Driving the Future of Business, 2008, Crown Business.

http://www.ideastorm.com/ (20.04.2014).

http://mystarbucksidea.force.com/ (20.04.2014).

https://zineinc.com/pl/ (20.04.2014).

Janasz W., Kozioł K., 2007, Determinanty działalności innowacyjnej przedsiębiorstw, Polskie Wydawnictwo Ekonomiczne, Warszawa.

Jelonek D., 2012, The Role of the Internet in Open Innovations Models Development, "Business Informatics", vol. 1 (23), pp. 38-47.

Jelonek D., 2013, Prosumption in Creating Value for the Customer, Proceedings of International Scientific Conference "Business Management - Practice and Theory in the 21st Century", 6-7 June 2013, Nitra, Slovakia.

Jelonek D., 2014, Personalizacja jako determinant sukcesu wspótpracy z klientem $w$ przestrzeni internetowej, [w:] Zarządzanie strategiczne. Rozwój koncepcji i metod, red. R. Krupski, Prace Naukowe Wałbrzyskiej Wyższej Szkoły Przedsiębiorczości, Wałbrzych, s. 267-278.

Li Ch., Bernoff J., 2000, Marketing technologii społecznych, czyli jak wykorzystać Web 2.0 w twojej firmie, MT Biznes, Warszawa.

Peters Th., Waterman R.H., 2000, Poszukiwanie doskonatości w biznesie, Medium, Warszawa, s. 45-49.

Prahalad C.K., Ramaswamy V., 2003, Future of Competition: Co-Creating Unique Value with Customers, Harvard Business School Press Books.

Prahalad C.K., Ramaswamy V., 2003a, The New Frontier of Experience Innovation, MIT Sloan Management Review, s. 12-18.

Reinhold O., Alt R., 2012, Social Customer Relationship Management: State of the Art and Learnings from Current Projects, 25th Bled eConference eDependability: Reliable and Trustworthy eStructures, eProcesses, eOperations and eServices for the Future, 2012, Bled, Slovenia.

Rosted J., 2005, User-Driven innovation. Results and recommendations, FORA, Copenhagen. 


\section{THE EFFICIENCY \\ OF INTERNET COMMUNICATION CHANNELS WITH THE CUSTOMER IN THE PROCESS OF INNOVATION CO-CREATING}

Summary: Together with the development of information and communication possibilities of the Internet there is an increase of the role of the customer as the partner in the process of co-creating innovation with the utilization of widely understood model of open innovations. The aim of the article is the assessment of the efficiency of communiaction channels used by firms in relations with the customer. In the assessment there were used findings of research carried out among students who declared activities in scope of: notifyings innovative ideas, testing of products (services) or undertaking the role of a consultant. The assessment took into account the criteria of comfort, speed and efficiency from the perspective of customer and the reaction of a company in the given channel of communication. E-mail, sms, forum, blog, community portal are comfortable but their utilization by companies requires improvement in respect of rate of reaction and efficiency. The channels of communication in the synchronous mode were highly evaluated in respect of efficiency and comfort: telephone, chat, video conversation and Skype. The best but still little widespread solutions are platforms for ideas reporting and the collaboration with the user which are created within company's portals.

Keywords: internet communiaction channels, efficiency of Internet communication channels, co-creation, innovation. 